\title{
Çeviri Projelerinde Süreç: Engelsiz Erişim Örneği
}

\author{
Project Design in Translation Studies: The Example from an Media Accessibility \\ Project
}

\author{
Araştırma/Research
}

\author{
Ayşe Şirin OKYAYUZ*, Sinem SANCAKTAROĞLU BOZKURT** \\ *Doç. Dr., Hacettepe Üniversitesi, Edebiyat Fakültesi, Mütercim ve Tercümanlık Bölümü, \\ sirinokyayuz@hacettepe.edu.tr, ORCID ID: orcid.org/0000-0001-7512-2764 \\ **Dr. Öğr. Üyesi, Hacettepe Üniversitesi, Edebiyat Fakültesi, Mütercim ve Tercümanlık Bölümü, \\ ssbozkurt@hacettepe.edu.tr, ORCID ID: orcid.org/0000-0003-0376-0358
}

\section{ÖZET}

Çalışmada öncelikle proje yönetimi kavramı açıklanmış, ardından Türkiye'de ve dünyada çeviribilim ve engelsiz erişim konulu projelere örnekler sunulmuştur. Proje tasarımına odaklanılan sonraki bölümde, Türkiye'de Sesli Betimleme Derneği [SEBEDER] tarafından yürütülen bir projeden somut örneklerle proje tasarımı, uygulaması ve kontrol aşamasında izlenmesi gereken adımlar ve dikkat edilmesi gereken konulara değinilmiştir. Sonuç bölümünde, özellikle engelsiz erişim için çeviri bağlamında projelerin önemine vurgu yapılmış, proje adımları üstsel bir bakışla derlenmiştir. Sosyal bilimler alanında sürekli proje çağrılarının yapıldığı, desteklerin verildiği günümüzde, proje yapmak isteyen araştırmacılara yol göstermesi amacıyla anlatmaya çalıştığımız ve örnekler verdiğimiz bu çalışmamızın alana katkı sağlaması ve özellikle engelsiz erişim ve çeviribilim ekseninde alana katkı sağlayan araştırmalara ek olarak somut ürünlerin ortaya konabildiği projeleri teşvik etmesi temennimizdir.

Anahtar Sözcükler: çeviribilim, engelsiz erişim, proje tasarımı, proje kalitesi, engellilik

\section{ABSTRACT}

The study was conducted at the intersection between translation studies and project studies in a period when there is an ongoing interest for the projects on accessible media and translation, a contemporary sub-field of translation studies to set an example for the projects in Turkey and to encourage young researchers in the field. The first part of the study deals with the concept of project management. This is followed by a section in which projects on translation studies and accessible media in Turkey and in the world are exemplified. In the second part, the project design, project implementation and control phases and such are explained with examples from a project carried out by SEBEDER (Audio Description Association). In the conclusion, the importance of 
translation projects, particularly those on accessible media, is emphasized focusing on project phases. This study, penned to guide researchers who want to undertake projects, will hopefully contribute to the field and encourage projects on the axis of accessible media and translation studies.

Keywords: translation studies, accessible media, project design, project quality, disability

\section{Giriş}

Proje yönetimi, kısaca, belli süreçlerin, yöntemlerin, becerilerin, bilgilerin ve deneyimlerin belirlenmiş proje hedefleri çerçevesinde yürütülmesi ve/ya uygulanması olarak tanımlanabilir. Bir projede belli bir zaman çizelgesi doğrultusunda ve belli bir bütçe içinde bir 'sonuç/çıktı' ortaya konur (What is project management?, t.b.).

Projelerin özgün olması, belli bir süreyle kısıtlı olması, önceden planlanmış hedeflere hizmet etmesi veya çıktılar ortaya konması beklenir. Bir projede zaman kısıtına uyulması, maddi kaynakların etkin yönetimi önemliyken, kuşkusuz en önemli unsur sürecin etkin bir şekilde işletilmesi ve proje çıktılarının amaçlanan hedefe hizmet edip etmediğinin kalite kontrolünün yapılmasıdır. Ancak, proje tasarlamak ve yürütmek bu kısa anlatıda yansıtıldığı kadar kolay olmayabilir. Projeler, içeriklerine ve amaçlarına göre karmaşık bir hâl alabilir ve bir projenin tasarımı, planlaması, uygulaması, kontrol edilmesi ve gerekirse değişikliklerle iyileştirilmesi zorlu bir süreçtir.

\subsection{Türkiye'de Çeviribilim Projelerine Örnekler}

Günümüzde, yirmi yıl öncesine kıyasla, çeviribilim alanında ve çeviribilim ile diğer bilim alanlarının kesiştiği noktalarda çok daha fazla sayıda proje desteklenmektedir. Uluslararası kurumların ana konusu çeviribilim olmasa da çeviribilim ile başka alanların kesiştiği disiplinlerarası projelere verdiği destekte bir artış ivmesi gözlemlenmektedir. Özellikle dünya genelinde bakacak olursak, örneğin, tek bir site üzerinden bile Avrupa Birliği projelerinin çağrıları incelendiğinde (bkz. EU Calls, 2020) kültür, görsel-işitsel medya ve iletişim, eğitim, toplumsal cinsiyet araştırmaları gibi çeviribilimde de işlenen konuları yansıtan yaklaşık yirmi iki farklı alan başlığı altında, sadece 2020 yılı içerisinde toplamda $4863 \mathrm{AB}$ ortağı ile, 193 yeni proje çağrısı yapıldığı görülebilir.

Geniş çaplı başka girişimlerden de bu bağlamda bahsetmek mümkündür, örneğin AB'nin bir ajansı olan EACEA (Education, Audiovisual and Culture Executive Agency) "Yazın Çevirisi" başlıklı bir girişim başlatmıştır (EACEA, 2020); Avrupa Komisyonu, Bologna Translation Service (2007-2013) adı altında yürüttüğü projeyi yenilemiştir (Bologna Translation Service, t.b.) ve her geçen gün, hemen hepsi çevrimiçi olmak üzere, onlarca yeni proje olanağı ve çağrısı yapılmaktadır.

Türkiye özelinde bakacak olursak, TR Dizin Proje Tarama arama motorunda "çeviri" kelimesini aratarak, ülkemizde çeviribilim alanında 1960-2021 yılları arasında yürütülen TÜBITAK destekli projeleri incelediğimizde, 12 tane proje karşımıza çıkmıştır. Bu projelerin bitiş tarihleri çoğunlukla 2000'li yıllara denk gelmektedir. 
Bu projelerin hepsinde anahtar kelimeler arasında ya da içerikte "çeviri" kelimesi yer almakla birlikte, çeviribilim bölümlerinden araştırmacılar tarafından, çeviribilim bakış açısıyla yürütüldüğü düşünülen proje sayısı üçtür. İlgili projeler (proje bitiş tarihleri ile birlikte) şu başlıklar altında verilmiştir: Sanal Dünyalarda Sözlü Çeviri ve Sözlü Çeviri Eğitimi (2017); Çeviri Çalışmalarına Ekoeleştirel Bir Bakış: (Yeniden) Çeviri Yoluyla Çeviri Çocuk Edebiyatında "Çevre Okuryazarlığına” Artsüremli Betimleyici Bir Yaklaşım (2017); Sözlü Çeviri Türü, Yönlülük ve Metin Türü Parametreleri Bağlamında Sözlü Çeviri Çalışmalarında Belirtikleştirme Kavramına Dizgeci İşlevsel Dilbilgisi Temelli Bir Yaklaşım (2014).

Geriye kalan diğer dokuz proje ise ilgili konularda bibliyografya çalışması sunduğu, unutulan eserleri çeviri yoluyla kültür repertuarımıza kazandırdığı, mühendislik ve çeviribilimin keşişim noktasında çeviri alanını kapsadığı ve Türkçe ve İngilizce film altyazılarından elde edilen cümle karşılıkları kullanılarak makine öğrenimi yaklaşımlarını incelediği; makine çevirileri için veri setleri oluşturmayı hedeflediği, vb. için önemlidir. Bu projeler, proje bitiş tarihleri ile birlikte, sırasıyla şöyledir: Türk Edebiyatında Tefrika Roman Tarihi (1831-1928) (2017); Aristoteles ve İbn-i Sina'nın Ruh Kavrayışlarının Karşılaştırmalı ve Eleştirel Değerlendirilmesi (2017); Ortaklaşa Oluşturulmuş Yarı-Yapısal Kaynaklardan Kelime Anlamlarının Keşfedilmesi ve Kelime Anlamları Ağı Oluşturulması (2017); Duygu Sözlüğü Kullanarak Kural Tabanlı Türkçe Duygu Analizine Yeni Bir Yaklaşım (2017); Türkiye Türkçesinde Fiilimsiler (2017); Telekomünikasyon Sistemlerinde Konuşma Tanıma, Sentezleme ve Uygulamaları (2005); İngilizce-Türkçe İstatiksel Çeviri Sistemi Prototipi Geliştirilmesi (2008); Türkmence-Türkçe Bilgisayarla Çeviri (2009); Biçimsel Betimleme Tekniklerine Dayalı Iletişim Yazılımı Belirtimi, Doğrulanması, Üretimi ve Sınanması (1994).

Aynı şekilde, aynı arama motoru üzerinden, farklı anahtar kelimeler ile ("çevirmen", "translation", vb.) arama yapıldığında çıkan sonuçlar arasında doğrudan çeviribilim bağlamında ele alınacak bir diğer proje de Tahir-Gürçağlar'ın yürütücülüğünü üstlendiği The Role of Translation in the Process of Globalization in Slovenia and Turkey (2011) başııkı projedir (daha ayrıntılı bilgi ve proje yürütücüleri, araştırmacıları, proje tam metni, vb. için bkz. https://app.trdizin.gov.tr/ara?from=1960\&to=2021\&database=Proje\&query=defaultSe archField-AND-\%C3\%87eviri\&order=score-DESC).

TÜBITAK projelerine ek olarak, Avrupa Birliği ve Avrupa Komisyonu destekli projeler ile ulusal ve uluslararası, kamu ve özel kurumların desteklediği projeler de bulunmaktadır. Özellikle çeviribilim eğitimi verilen bölümlerin olduğu üniversitelerin bilimsel araştırma projeleri koordinasyon birimlerinin de çeviribilim konulu projeleri desteklediği görülmüştür (daha ayrıntılı bilgi ve farklı üniversitelerden çeviribilim araştırmacılarının yürüttüğü projeler için bkz. https://transint.boun.edu.tr/tr/arastirmaprojeleri; https://bapsis.hacettepe.edu.tr/ASProjeArama.aspx, vb.).

\subsection{Alan Yazınında Çeviribilim ve Engelsiz Erişim Projelerine Örnekler}

Çeviribilim alanında proje yapılan en güncel alt alanlardan biri de engelsiz erişim ve çeviridir. Örnek, olarak 2017-2020 yılları arasında Avrupalı ortakların ve 
akademisyenlerin engelsiz erişim için yürüttükleri birkaç proje verilebilir; günümüzde devam eden birkaç projeye bakarak dünya genelinde engelsiz erişim ve çeviri alt alanındaki farklı açılımları da görmek olasıdır. Bu projelere örnekler şu şekildedir: 20172020 H2020-ICT-2016-2 761999 EasyTV Easing the Access of Europeans with Disabilities to Converging Media and Content (bkz. About project, 2016); 2017-2020 H2020-ICT2016-2 761974 ImAc Immersive Accessibility (bkz. ImAc, 2020); 2017-2019 H2020-MSCA IF 2016752659 UMAQ Understanding Media Accessibility Quality (bkz. UMAQ, 2019); 020-2025 COST ACTION 19142 LEAD ME Leading Platform for European Citizens, Industries, Academia and Policymakers in Media Accessibility (bkz. LEAD ME, 2020); 2020-2024 ICT44 957252 MEDIAVERS A Universe of Media Assets and Co-creation Opportunities at Your Fingertips (bkz. MediaVerse, 2020); 2020-2023 H2020-SC6TRANSFORMATIONS 870610 TRACTION Opera Co-creation for a Social Transformation (bkz. TRACTION, 2020); 2020-2023 H2020-SC6-TRANSFORMATIONS 870939 SO-CLOSE Enhancing Social Cohesion through Sharing the Cultural Heritage of Forced Migrations (bkz. So-CLOSE, 2020); 2019-2022 ERASMUS+ 2019-1-FR01-KA204-062381 IMPACT Inclusive Method Based on the Perception of Accessibility and Compliance Testing (bkz. IMPACT, 2020); 2019-2021 RAD PGC2018-096566-B-I00 Researching Audio Description: Translation, Delivery and New Scenarios (bkz. RAD, 2019); 2019-2021 H2020- ICT28 825585 HELIOS A Context-Aware Distributed Social Networking Framework (bkz. HELIOS, 2018); 2018-2021 ERASMUS+ 2018-1-ES01-KA203-050275 EASIT Easy Access For Social Inclusion Training (bkz: EASIT, 2016); 2018-2021 ERASMUS+ 2018-1-DE01KA203-004218 LTA Quality Training in Real Time Subtitling Across EU and EU Languages (bkz. LTA, 2020).

Günümüzde Türkiye'de de artık engelsiz erişim ve çeviri alanlarında yeni projeler yürütülmekte, özellikle üniversitelerin ve engelsiz erişime gönül vermiş üretici STK'ların desteğiyle çalışmalar ilerletilmektedir (bkz. Sesli Betimleme Derneği [SEBEDER], 2020a). $\mathrm{Bu}$ projelere örnek vermek gerekirse, Sesli Betimleme Derneği'nin (SEBEDER) 25 Ağustos-09 Ekim 2020 tarihleri arasında çeviribilimciler, işaret dili çevirmenleri, sesli betimlemeciler, vb.'nin katkıları ile yürüttüğü Sağır, İşitme Engelli ve Görme Engelli Çocukların Televizyon Programlarına Engelsiz Erişimi Projesi; yine SEBEDER'in ŞubatEylül 2019 yılları arasında yürüttüğü Ana Dili İşaret Dili Olan Çocukları Türkçe Çocuk Edebiyatı Yazarlarının Eserleriyle Buluşturmak İçin Pilot Proje; Ekim 2018-Şubat 2019 tarihleri arasında yürütülen Türkçe Dil İçi Ayrıntılı Altyazı Çevirisi Uygulamalarını Araştırma ve İyileştirme Projesi (ayrıntılar için bkz. SEBEDERa, 2020) sayılabilir.

Mart ve Nisan 2021 tarihlerinde Hacettepe Üniversitesi Mütercim-Tercümanlık Bölümünde yapılan seminerler dizisi (Görsel-işitsel Çeviri ve Projeler) de engelsiz erişim alanındaki projelerin önemine ve ülkemizde proje yürütülmesi gereksinimine dikkati çekmiştir. Aşağıda verilen tarihlerde belirtilen katılımcılar sürece destek vermiştir:

\section{Seminer}

26 Mart 2021 10:00-11:30 Prof. Pilar Orero (Universidad Autónoma de Barcelona İspanya) ve Doç. Dr. Şirin Okyayuz (Hacettepe Üniversitesi)

\section{Seminer}


9 Nisan 2021 10:00-11:15 Prof. Anna Matamala (Universidad Autónoma de Barcelona İspanya) ve Dr. Öğr. Üyesi Sinem Bozkurt (Hacettepe Üniversitesi)

\section{Seminer}

9 Nisan 2021 11:30-13:00 Prof. Pablo Romero-Fresco (Universidade de Vigo İspanya ve University of Roehampton Birleşik Krallık) ve Ebru Kanık (Bilkent Üniversitesi)

Özel olarak paylaşılan duyuru metninde de bu konular vurgulanmış ve özellikle genç araştırmacılara çağrıda bulunulmuştur:

Türkiye'de çeviribilim alanında görsel-işitsel çeviri araştırmalarına ilginin arttığı bu dönemde, Avrupa'da engelsiz erişim kapsamında çok değerli projeler üreten alanın önde gelen akademisyenleri ve Türkiye'de engelsiz erişim için projeler tasarlamış ve yürütmüş olan meslektaşlarla etkileşimli bir seminer dizisinde sizleri de aramızda görmekten memnuniyet duyarız.

Konuşmacılar görsel-işitsel çeviri ve engelsiz erişim alanlarında yürüttükleri projelere odaklanacaklardır. Projelerin üstsel bir bakışla sunumundan sonra, devam eden projeler ve etkileri hakkında bilgi de paylaşılacaktır. Son olarak da yeni açılımlarla gelecekte yapılabilecek çalışmalara ilişkin fikirler paylaşılacaktır.

Seminerlerde tartışılan başlıca konulara bakacak olursak bazı noktalar ortaya çıkmaktadır.

1) Engelsiz erişim kapsamında çok disiplinli ekiplerle, kullanıcı odaklı, ampirik çalışmalar çok önemlidir.

2) Genelde bir kurumun maddi desteği ile gerçekleşen, çok farklı bakış açılarına sahip uzmanların yer aldığı projelerde, çeviribilimci uzman (incelenen olguya çok yönlü bakabilen, ürünü ortaya koyacak kişiler arasında olduğundan tüm uzmanların ilettiği bilgileri içselleştirmesi gereken) istisnai konumundan dolayı tüm projeyi bir arada tutmak için, arabuluculuk (aracılık) işlevini de üstlenen bir profesyonel olabilmektedir.

3) Çeviribilimci uzman kimi zaman da proje verilerinin 'kullanılması' için politika yapıcılarla ve benzeri güç mercileri ile müzakere eden veya en başta engellilerin haklarını, ayrıca alanda çalışan profesyonellerin de haklarını koruyan bir aktivist ruhla hareket edebilmektedir.

4) Belirtilen türde projelerde mutlaka somut bir 'ürün' ortaya konmalıdır. Ancak bu 'ürün' çağdaş araştırma yönetimleriyle ve etik çerçeveye uyarak ortaya konan ve standartların, yeterliliklerin yazımını ya da gelecekteki araştırmaları yönlendirebilecek merkezî bir bulgu, istatistik ve/ya yaklaşım da olabilir.

5) Çağdaş projelerde kimi zaman 'engelsiz erişim' ve/ya 'çeviri' konunun odağı olacaktır (örneğin çalışmada örneklenen proje), kimi zaman daha başka bir konuya hizmet edecek bir araç olacaktır (örneğin mültecilerin toplumsal bütünleşmesi projesinde engelsiz erişim sağlanması için atılan adımlar), kimi zaman da çok etmenli bir projenin sadece bir ayağı olacaktır (örneğin görme engellilere tiyatrolarda ve balede engelsiz erişim sağlanması için özel teknolojilerin geliştirilmesi). Tüm bu projeler alana katkı sağlayacak niteliktedir. 
Daha birçok konuya değinilen ve projelerin örneklendiği seminerler dizisinden edinilen deneyimle, Türkiye'de, özellikle de sözü edilen alanda, projelerin öneminin arttığı ve projelerin oluşturulmasını ve yürütülmesini desteklemek amacıyla engelsiz erişim için çeviri projeleri tasarımı, yönetimi ve benzeri hakkında çalışmaların da ortaya konması gerektiği açıkça belirtilmiştir.

Bir proje, özünde, bir araştırma içereceğinden en önemli unsurlardan biri de alandaki araştırma tekniklerinin bilinmesidir. Bu makalenin odağı araştırma teknikleri değil, proje sürecidir; ancak, bu tür projelerde araştırma tasarımı kılavuzu olarak kullanılabilecek birçok kaynağın olduğunu da vurgulamak gerekir. Bu kaynaklar kısaca şu şekilde sınıflandırılabilir: (a) Çeviribilimde araştırma tasarımı için bkz. Mellinger \& Hanson, 2017; Saldanha \& O'Brian, 2013; Williams \& Chesterman, 2002; (b) Genel kaynaklar için bkz. Creswell \& Creswell, 2018; Dawson, 2009; (c) Çeviribilimin bir alanında/yaklaşımında araştırmaya odaklanan kaynaklara örnek olarak bkz. Hatim, 2013; Kruger, Wallmach \& Munday, 2011; Marais \& Meylaerts, 2019; Munoz Martin, 2016.

Günümüzde hızla artan proje çalışmalarına destek vermek amacıyla, bu çalışmada yukarıda sözü edilen projelerden, Ağustos-Ekim 2020 tarihleri arasında Sesli Betimleme Derneği [SEBEDER] çatısı altında yürütülen, büyük olasılıkla Türkiye'de şimdiye kadar yapılmış en kapsamlı engelsiz erişim projesi, proje döngüsü ilkeleri çerçevesinde anlatılmaktadır. Çalışmanın ikinci bölümünde proje döngüsünün planlama, uygulama ve kontrol aşamalarına değinerek sözü edilen projede yapılanlar aktarılmış, proje yönetimi ile çeviribilim projeleri bilgileri harmanlanarak çok disiplinli bir bakış açısı sunulmaya çalışılmıştır. Proje çıktıları proje sonucunda değerlendirilmiş olup (Bkz. Bozkurt \& Okyayuz, 2020; SEBEDER, 2020b) çalışmanın odak noktası çeviribilim projeleri yürütülmesine katkı sağlamak olduğundan, proje çıktılarına çok kısaca sonuç bölümünde değinilmiştir. Ülkemizdeki engelsiz erişim için çeviri projelerinin sayısının artacağı umuduyla proje tasarlamak, planlamak, uygulamak, kontrol etmek ve iyileştirmek isteyecek genç akademisyenlere emsal olması amacıyla, örneklerle engelsiz erişim için çeviri bağlamında proje süreci üzerinde durulmuştur.

\section{Proje Tasarımı}

Bir proje belli evrelerden oluşur; buna proje döngüsü adı verilir. Watts'a (2014) göre bir döngü dört aşamadan oluşur: başlangıç, planlama, uygulama, tamamlama. Başlangıç aşamasında projenin amacı veya projeye neden gereksinim duyulduğu belirlenir. Genelde çeviribilim alanındaki projelerde ya araştırmacı(lar)nın kendisi alandaki çalışmalarda bir eksiklik görmekte ya da bir işveren ve/ya kurum bir eksikliği doldurmak için proje yapılmasını önermektedir. Bu aşamada birkaç olasılık söz konusu olabilmektedir. Proje önerisi bir işverenin veya bir kuruluşun isteği üzerine tasarlanabilir, örneğin, bir kurum gerçekleştirmek istediği bir girişim için akademik araştırmayla desteklenmiş bir şablon, bir tasarım, bir yol haritası ve benzerini isteyebilir. Proje salt akademik amaçla bir araştırmacılar grubunun incelemek istediği bir konu olabilir, örneğin üniversitelerde engelsiz erişim için çeviri eğitimi oluşturulması için bir girişim söz konusu olabilir. Proje önerisi ayrıca (yukarıda da belirtildiği gibi) daha geniş kapsamlı bir proje içinde engelsiz erişim araştırması da olabilir, örneğin sağlık hizmetlerine erişimde 
kurulacak teknolojik sistem altyapısında otomatik canlı altyazı veya simülasyonla işaret dili çevirisi eklenmesi için teknolojik cihazlara yüklenecek bütünce derlenmesi söz konusu olabilir. Başlangıç aşamasında projenin amacı yürütülecek projede araştırmacılardan ne beklendiği sorusunun cevabı olacaktır. Merkezî konu tasarlanacak projenin belirlenen gereksinime cevap verip vermeyeceğidir.

$\mathrm{Bu}$ aşamada belki de en önemli olan unsur bir fizibilite (uygulanabilirlikyapılabilirlik) çalışmasıdır.

Projeye başlarken iki ana konu gündemdedir: "böyle bir proje yapılabilir mi?” sorusu ve "bu proje yapılmalı mı? (alana hizmet edecek mi?)" sorusu. Bu soruların cevapları olumluysa projeye başlanması için bir proje yöneticisi veya ana sorumlu tayin edilir. Ana çıktıların ne olacağı ve proje ekibinin kompozisyonu belirlenir. Ancak bu aşamadan sonra planlamaya geçilir.

\section{Engelsiz Erişim için Çeviri Projelerinin Planlama Aşamasında Dikkat Edilecek Konular}

Çalışmada ele alınacak olan Sağır, İşitme Engelli ve Görme Engelli Çocukların Televizyon Programlarına Engelsiz Erişimi Projesi, SEBEDER'in yönetiminde gerçekleşmiştir. Projeye, Türk işaret dili (TID) çevirmenleri, görsel-işitsel çevirmenler, Sağır editör/çevirmenler, ayrıntılı altyazı çevirmenleri ve sesli betimleme metin yazarları, çocuk edebiyatı yazarı/çevirmeni/araştırmacısı (İstanbul Üniversitesi), engelsiz erişim uzmanı ve çeviribilimci (Bilkent Üniversitesi, Hacettepe Üniversitesi), okul öncesi eğitim uzmanı (Sinop Üniversitesi), Sağır anketörler ve teknik uzmanlar katkı sağlamıştır. Katkı sağlayan paydaşlardan da anlaşıldığı üzere projenin içerik ve kapsamına uygun uzmanların yer alması projenin başarısı açısından önemlidir. Projenin ana amacı şu şekilde belirlenmiştir (SEBEDER, 2020b, s. 2):

Görme engelli çocuklar ile Sağır kültürde büyüyen ve Türk Işaret Dilini (TiD'i) ana dili olarak kullanan çocukların, işitme engelli olup ayrıntılı altyazı ile programlara erişimi olan çocukların;

- Çocuk programlarına duydukları ilgiyi arttırmak;

- Söz konusu alıcıların programları izleme zevkini perçinlemek;

- Yayınlara erişimle gelişen 'yaşam ve toplumlaşma' becerisini geliştirmek,

- Diğer çocuklar ile aynı haklara sahip olarak, yaşıtlarıyla eşit edinimlerini ve erişimlerini sağlamak.

Yukarıda paylaşılan açıklamadan da anlaşılacağı üzere proje bir işverenin talebi üzerine, bir STK'nın yönetiminde, uygulamacıları ve akademisyenleri bir araya getirmek suretiyle başlatılmıştır. Türkiye'de engelsiz erişim için yapılan çevirinin yaygınlaşması ve kalitesinin idame ettirilmesini önceleyerek tasarlanmıştır.

Bir projenin başarısı, baştan doğru tasarlanmış olmasına bağlıdır. Dolayısıyla, ülkemizde de, yurt dışında da özellikle kurumsal maddi destekle yürütülecek tüm projelerde projeyi yürütecek kurum ve/ya kişinin tasarımının doğruluğunu ve etkinliğini 
kontrol etmek amacıyla birçok soru sorulur ve matbu bir proje formu doldurulması ve tüm açılardan projenin an azından tasarımının doğruluğunun tespit edilmesi önemlidir. Bu amaçla üniversitelerin bilimsel araştırma projeleri koordinasyon birimlerinin ayrıntılı kılavuzlar hazırladığı (örneğin, bkz. Bilimsel Araştırma Projeleri Uygulama Esasları \& Yardımcı Bilgiler (Hacettepe Üniversitesi Bilimsel Araştırma Projeleri Koordinasyon Birimi, 2021); Bilimsel Araştırma Projeleri El Kitabı (Boğaziçi Üniversitesi, BAP İdari Koordinatörlüğü, 2020) görülmektedir.

Lewinson'a (2011) göre, ilk olarak bir projenin açık ve belirgin bir şekilde tanımlanması gerekir. Tüm aktörlerin proje kapsamı ve amacında mutabık kalmaları en önemli adımdır. Tüm proje paydaşları, projenin ne amaçla ve kapsamda yapıldı̆̆ını ayrıntısı ile bilmelidir, ancak projeye neyin dâhil edilmediğinin de bilincinde olmalıdırlar.

$\mathrm{Bu}$ ilk tasarım yapıldıktan sonra, planlama aşamasındaki ilk adımın atılması önemlidir. Projenin amacı daha genel bir tanımlamayı içerirken, proje hedefleri ve çıktıları detaylı bir şekilde tartışılmalı ve yazılmalıdır.

Çalışmada örneklenen projede bu aşamalar aşağıdaki şekilde kaleme alınmıştır (SEBEDER, 2020b, s. 3-11):

Proje ana hedefleri: Ana dilleri işaret dili olan Sağır ve/ya işitme engelli çocuk alıcılar için işaret diliyle ve/ya ayrıntılı altyazıyla erişilebilir çeviri kaynaklar oluşturmak, görme engelli çocuklar için programlara sesli betimleme metinleri eklenmesi için kaynaklar oluşturmak. Yukarıda belirtilen kapsamdan elde edilecek veriler ve dönütlerle benzer kaynakların oluşturulması için akademik açıdan onanmış bir proje döngüsü ve bir çeviri kılavuzu oluşturmak. Oluşturulan proje döngüsünden elde edilen deneyimle, söz konusu alıcıların, sözü edilen programlara erişimlerini destekleyecek çalışmalara katkı sağlamak ve bu çalışmaları yaygınlaştırmak. Proje kapsamında çeviribilimcileri, işaret dili çevirmenlerini, ayrıntılı altyazı çevirmenleri, sesli betimleme metin yazarları ile editörlerini ve engelsiz erişim için çeviri yapan SEBEDER uzmanlarını bir araya getirerek bir iletişim ve mesleki paylaşım köprüsü kurmak. Akademik araştırmalardan ve SEBEDER'in uygulamalarından elde edilen, erişimde çeviri niteliğini geliştirmek için kullanılabilecek bilgileri ve birikimi uygulamaya yansıtmak. Sağır, işitme engelli ve görme engelli çocukların birer birey olarak gereksinimlerine hizmet edecek bir proje kılavuzu hazırlamak.

Proje ana çıktıları ise şu şekilde açıklanmıştır (SEBEDER, 2020b, s. 12):

Çeviriler: İ̧̧veren tarafından teslim edilen 24 adet görsel-işitsel metnin işaret dili ve ayrıntılı altyazı ile çevrilmiş ve sesli betimleme metni yazıımış sürümleri;

Kılavuzlar: Proje kapsamında edinilen verilerden ve dönütlerden yola çıkarak çocuk programlarının işaret dili ve ayrıntılı altyazı ile çevirileri ve sesli betimleme metin yazımı ile ilgili akademik olarak doğrulanmış 'iyi uygulama' kılavuzları ortaya koymak.

Odak grubu verileri: Proje kapsamında yapılan çevirilerin hedeflenen çocuk alıcı kitleler tarafından değerlendirilmesini içeren bir odak grubu çalışmasının sonuçlarını ortaya koymak. Proje kapsamında yapılan çevirilerin hedeflenen görme engelli ebeveyn alıcı kitleler ve çocukları görme engeli olan ebeveyn alıcı kitleler tarafından değerlendirilmesini içeren bir odak grubu çalışmasının sonuçlarını ortaya koymak.

Bu adımın sonunda, yukarıda örneklenen projeden de anlaşılacağı üzere, proje ekibinin elinde ne yapılması gerektiği sorusunun cevabı bulunacaktır. Ancak, bu süreç, 
planlama aşamasının henüz ilk adımı olduğundan, yapılacakların nasıl yapılması gerektiği sorusunun cevabını da vermek gerekecektir.

Darnall ve Preston'a (bkz. 2016, Bölüm 4-6) göre bu aşamada gider ve harcamaların dökümünün hazırlanması ve zaman çizelgelerinin oluşturulması önemlidir. Bu konular proje yöneticisi tarafından paydaşlarla iletişim hâlinde düzenlenir.

Proje tasarım aşamasında iletişim ağlarının sağlam bir şekilde kurgulanması projenin başarısı açısından çok önemlidir. Rajkumar (2010) bir projede etkin iletişim sağlanması için ilk önce iletişim gereksinimlerinin belirlenmesi (örneğin, proje ekibindeki kişilerin listesi, iletişim bilgileri), proje ekibindekilerden kimlerin (örneğin, kim hangi sorumlulukları yüklenmiştir?), ne zaman? (örneğin, ayrıntılı iş akışı zaman çizelgesi), hangi ortamdan? (örneğin, toplantı-sanal veya canlı, telefon görüşmesi vb.), hangi konularda (örneğin, projedeki hangi çıktıdan önce veya sonra?) görüşmeleri gerektiğinin belirlenmesinin öneminin altını çizer.

Örneklenen projeden yola çıkarak Türkçe konuşma dili ve Türk İşaret Dili gibi iki ayrı iletişim dilinin olduğu projelerde yazılı iletişimde kültürel farklılıklara dikkat etmek gerekir. Toplantı ortamlarında da (iletişim kuracak herkes aynı iletişim dilini kullanmıyorsa) çevirmen bulundurulması önem kazanacaktır. Söz edilen projede hem Sağır uzmanlar hem de görme engelli uzmanlarla diğer uzmanlar bir arada çalıştıkları için tüm görüşmeler ve toplantılar herkesin erişim sağlayacağı şekilde tasarlanmıştır.

Proje tasarımı ile ilgili evrak yazılı olarak iletilmiş, görüşler yazılı olarak alınmışken, tüm toplantılarda gerektiği ortamlarda görme engelli paydaşlar için sesli betimleme, Sağır uzmanların katkıları sunulurken de işaret dili (çevirisi) desteği sunulmuştur. Proje döngüsü içinde ilk günden proje bitimine iletişim temel unsurlardan biridir. Sözü edilen projede paydaş toplantıları Zoom üzerinden, WhatsApp ve Gmail-Meet uygulamaları üzerinden yapılmıştır.

Tüm proje sürecinde iletişim ve planlama, merkezî önemde olduğundan her bir adım ilk başta belirtilmiş (iletişimle aktarılmış), ardından uygulanmış (ilgililere iletilmiş), son olarak da kayıt altına alınmıştır (kılavuzlar ve proje evrakı hazırlanmıştır).

Proje birkaç ana bileşenden oluşmuştur. Tüm paydaşlar (amaç, hedef, çıktı ve hedefler doğrultusunda) çalışma çizelgesi, görev dağılımı, kaynak kullanımı ve benzeri konularda toplantı yapmış ve proje işleyişine ilişkin çatı oluşturulmuştur.

Paydaşların geniş proje kapsamında bir ortak çalışma felsefesi oturtmaları önemsenmiştir. Ancak, proje hedeflerinde belirtilenler konusunda anlaşılabilmesi için birlikte çalışacak alt gruplar (sesli betimleme ve işaret dili/ayrıntılı altyazı grubu) arasında da toplantı(lar) yapılmıştır. Paydaş profillerinin tanıtılması ve açıklanması; projenin somutlaştırılması, sürecin açıklanması, zorlukların belirlenmesi; alt gruplar içinde iş dağılımının yapılması, sorumlulukların belirlenmesi bu aşamada tamamlanmıştır.

Proje uzmanlarına göre (bkz. Shi \& Chen, 2006) bir projenin en önemli ekseni projede çalışacak insan kaynağı ve bunun yönetimidir. Dolayısıyla, sözü edilen projede bu aşamadaki en önemli konu uygulamada ürünleri ortaya koyacak olan ekibin merkezî üyeleri olan çevirmen ve editör profillerinin belirlenmesi olmuştur. Ülkemizde engelsiz 
erişim için çeviri türlerine ilişkin örgün eğitim çok kısıtlı olduğundan (bkz. Okyayuz, 2019) hatta birçok uzmanlık alanında olmadığından, sözü edilen türde projelerde çalışacak olan uzmanların birikimleri ve profillerinin ayrıntısı ile belirtilmesi önemlidir.

Çevirmen ve editör profilleri ayrıntıları ile irdelenmiş, pilot çalışmayı yürütecek olan uzmanlar bu kriterlere göre belirlenmiş ve aşağıda örneklenen şekilde daha sonraki çalışmalarda örnek profil belirlemek amacıyla, proje içerisinde de ayrıntısıyla kaleme alınmıştır. Aşağıda, kılavuzda yer alan pek çok örnekten bir tanesi verilmiştir (SEBEDER, 2020b, ss. 40-43):

Çocuk programları için ayrıntılı altyazı çevirisi yapacak olan çevirmenin aşağıdaki vasıflara sahip olması beklenir:

Altyazı çevirisi ile ilgili olarak:

1) Ayrıntılı altyazı çevirisi bilgisi ve deneyimi.

2) Ayrıntılı altyazı sürecinde kendisine sunulan kılavuzu takip edebilme profesyonelliği.

3) Çocuklara yönelik olarak tasarlanmış görsel-işitsel üründe, görsel ve işitsel düzgüleri bütünleşik olarak ve ayrı ayrı çözümleme becerisi- (Örneğin, görselden edinilen bilginin işitselde pekiştirme amacıyla tekrarlanması ile artık bilgi -fazla bilgi- olarak tekrarlanması arasındaki farkı saptayabilme deneyimi).

4) Ayrıntılı altyazı çevirisi uygulamasının zaman içinde alıcı profilin isteklerine ve özelliklerine, çalışma ve araştırmalara, uygulamada benimsenen esaslara göre evrileceğinin bilincinde olma ve sürekli mesleki gelişim ilkesini benimseme becerisi.

5) Sözlü dilde sesletimle anlamlanan nida ve ifadelerin yazılı dile geçişte anlaşıımasına özen göstermek için sözlü metinden yazılı metne çeviri geleneğine hâkim olma.

Teknoloji ile ilgili olarak:

1) Ayrıntılı altyazı çevirisi yapacağı kanalda kullanılacak altyapıya aşinalık

2) Ayrıntılı altyazı teknolojilerine hâkimiyet

Çeviri süreci ile ilgili olarak:

1) Ayrıntılı altyazı sürecini işverenin istediği sürede tamamlayabilecek deneyim ve birikim

2) Ayrıntılı altyazı kılavuzunda belirtilen sorunlu çeviri durumları ile ilgili olarak doğru çeviri seçimlerini yapabilecek dil içi çeviri deneyimi

3) Ürün tasarımında üç aşamayı profesyonel anlamda içselleştirme: -a) çevrilecek ürünü bütünsel olarak inceleme, b) çeviriyi yapma, c) özdenetim sürecini tamamlama

4) Ürünün taslak çevirisini oluştururken (ön araştırma sürecinde ve çeviri çıktısının özdenetim sürecinde) doğru ve kabul görmüş referans kaynaklarını saptayabilme, bunlara erişebilme ve bunları kullanabilme

5) Anlam odaklı çeviri ilkesini içselleştirmiş olma 
6) Çocuklara yönelik ürünlerde ürünün amacını (neden böyle bir ürüne gereksinim duyulduğunu) saptayabilme ve bu saptamadan yola çıkarak ürünün amacını (skopos) saptırmadan ürünü çevirebilme

7) Çocuklara yönelik tüm ürünlerin (yazın, film vb.) yetişkinlere yönelik ürünlerden farklı yaklaşımlarla ve ilkelerle tasarlandığı hakkında artalan bilgisi

8) Bağlam, kısıt ve parametreleri düşünerek gerektiği bağlamda kaynak metne sadakat gösterebilme, gerektiği bağlamda da metin uyarlama tekniklerine hâkim olacak ve farklı çeviri stratejilerini uygulayabilecek çeviri birikimine ve yaratıcılığa sahip olma

9) Sözlü dilden yazılı dile geçişte okuma hızı kısıtını, uzam kısıtını ve alıcı algı kısıtını göz önüne alarak ürün tasarımı yaparken sadeleştirme ilkesini (basitleştirme yapmadan ve iletiden ödün vermeden) uygulayabilme

Dil ile ilgili olarak:

2) Hitap edilecek çocuk alıcı yaş grubuna göre duygulara hitap edebilmek için dili doğru kullanabilme (Örneğin, çocuğa komik gelecek unsurları, üzücü gelecek unsurları saptayabilmek).

Alıcı ile ilgili olarak:

1)

Çocukların dil dağarcığına aşinalık.

2) Çocukların sözcük haznesine ve sözcük haznesi gelişimine ve geliştirme yöntemlerine aşinalık.

3) Farklı yaş grubundaki çocukların birikimlerini ve profillerini tartabilme ve belli bir alıcıya yönelik olarak ürün tasarlayabilme.

4) Çocukların medya okur-yazarlığı hakkında bilgi.

5) Işsitme engelli ve sağır çocuk profilleri hakkında art alan bilgisi.

6) Birden çok alıcı profiline (işitme engelli ve sağır, ana dili işaret dili olan vb.) hitap edebilecek ürün tasarlama geleneğinde benimsenecek esaslara aşinalık.

7) Çocuk programlarında kullanılan şarkı, efekt ve benzeri dış sesleri çocuk algısı içinde ifade edebilecek deneyime ve alıcı kitle bilgisine sahip olma.

Ekip çalışması ile ilgili olarak:

1) Ürün düzeltiminde editör ile çalışabilme ve geri dönüşleri değerlendirerek bir sonraki uygulamalara yansıtabilme becerisi.

2) Belli uygulamalarda bir çeviri ortağı ile çalışabilme becerisi (iki çevirmenin aynı ürünün farklı bölümleri üzerinde eşgüdümlü çalışması).

3) Kendisinden önceki çevirmenlerin ürünlerinden profesyonel bilgi edinebilme, edindiği bilgiyi ilkeler hâlinde düzenleme ve ilkeleri kendi çevirisinde uygulayabilme becerisi.

Yukarıda, özetlenen bilgiden de anlaşılacağı üzere, planlama aşamasının sonunda ortada projenin yaklaşımını belirleyecek bir amaç, projenin adımlarını belirleyecek hedefler, projenin içeriğinin ayrıntısını belirleyecek olan çıktıların dökümü 
tamamlanmıştır. Bunları gerçekleştirecek uzman ekip bir araya getirilmiş ve eşgüdümleri başlatılmıştır.

\section{Engelsiz Erişim için Çeviri Projelerinin Uygulama Aşamasında Dikkat Edilecek Konular}

Planlama aşamasını takiben, proje uygulama aşamasında dikkat edilmesi gereken çok çeşitli konular olacaktır. Bu aşamada insan kaynaklarının doğru ve etkin yönetimi, süreçlerin ilgili tüm paydaşlarca yakından takibi, anahtar ekip üyelerinin fikir alışverişi ve iletişim unsurları önem kazanmaktadır. Proje çıktılarına ulaşmak için oluşturulan planların uygulamadaki adımlarının iyi belirlenmiş olması ve aksatılmadan ve eksiksiz yerine getirilmesi amaç ve hedeflere ulaşılması için merkezî unsurlardır.

Caietti (2018) bu evrede dikkat edilmesi gereken on konu listeler. Bunlar kısaca şu şekilde özetlenebilir:

sürekli projenin amacını göz önünde bulundurmak ve bundan sapma olmadığına dikkat etmek;

iletişim kurarak proje yöneticisinin işini yapmasına olanak sağlamak;

etkin ve adanmış bir proje yöneticisi ve yönetim ekibine destek vermek;

alt ekipler arasında iletişimin sürekliliğini korumak -kopmalar olmamasına dikkat etmek;

hesap verebilirlik çerçevesinde gelişmeyi ve performansı izlemek;

projede 'birbirini dinleme' kültürünü yerleştirmek;

açık ve esnek olmak -gerekirse değişiklik yapmaya hazır olmak;

ekibin tamamladığı her aşamada başarısını ortaya koymak ve eksikliklerden öğrenmek;

ekip çalışmasının ilkelerinin ve etik duruşunun tüm çalışanlarca benimsenmesi;

projenin başarısına odaklanmak.

Bu konuları bir engelsiz erişim projesi kapsamında ele aldığımızda, kısaca şunları söyleyebiliriz: Proje engelli bireylerin görsel-işitsel ürünlere erişimini sağlamak için ortaya konmuştur. Dolayısıyla, bu bağlamda merkezî paydaşlar alıcı grubu temsil eden engellilerin kendileri olacaktır. Projenin her adımında bu kişilere hizmet edildiğinin unutulmaması ve bu kişilere danışmadan ve birikimlerine ve bilgilerine dayalı bir onay alınmadan ilerlenmemesi önemlidir. "Bizim hakkımızda biz olmadan asla" ilkesi (bkz. Harpur, 2017) bu tarz projelerin en önemli prensibidir. Illetişim kurulması gerektiği ilkesinden hareketle, özellikle de engelli grupların paydaş olarak yer aldıkları projelerde bireyin tüm proje sürecine ve akışına engelsiz erişimi olduğundan emin olmak ve bunu sağlamak önemlidir (bkz. Coe \& Wapling, 2010).

Alt proje grupları ile çalışılan sözü edilen türden projelerde 'fazla iletişim' diye bir konu da gündeme gelebilmektedir. Örneğin, engelsiz erişim kapsamında sesli betimlemeli sürümleri oluşturan ekibin süreci ile ayrıntılı altyazılı sürümleri oluşturan ekibin süreci ancak belli bir oranda kesişecektir. Dolayısıyla, bu alt ekiplerin kendi içlerinde eşgüdümlü çalışmaları ve çalışmaların ayrıntılarını paylaşmaları önemlidir, 
buna ek olarak bu çalışmaların içerik, döküm ve bilgilerinin her gruba iletilmesi önemlidir. Eğer farklı alt proje bileşenlerinde çalışan her üye, her grubun işini takip etmeye çalışırsa bir karmaşa doğacaktır. Bu bağlamda da proje yürütücüsü veya koordinatörünün rolü çok önemlidir. Her ekip üyesinin görevini belirlerken bu ekip üyelerinin kime nasıl bilgi vereceklerini, kiminle nasıl hangi konuda iletişime geçeceklerini de belirlemek önemli olacaktır. Yani aslında sürekli iletişim ilkesini benimserken, etkin ve etkili iletişim ve bu iletişimin eşgüdümü ilkesini benimsemiş olmak önemlidir.

Birbirini dinleme kültürü, açık ve esnek olmak ilkeleri özellikle vurgulanması gereken yaklaşımlardır. Orero ve Matamala (2018) çalışmalarında özellikle engelsiz erişim bağlamında ekip üyelerinin yaklaşımlarının ne kadar önemli olduğuna vurgu yaparlar.

Uygulama aşamasında yukarıda sayılan yaklaşımların benimsenmesi bir engelsiz erişim için çeviri projesinde atılması gereken tüm uygulama temel adımlarında esastır. Özellikle ortaya bir çeviri ürün de konan benzer projelerde, bu adımlar kısaca şu şekilde özetlenebilir:

- Tasarım ve ürünlerin incelenmesi,

- Illetilen kaynakların engelsiz erişime uygun hâle getirilmesi için eşgüdüm,

- Ana taslak çalışmalarının yapılması,

• İlgili erişim türünün eklendiği video sürümünün son hâline getirilmesi,

- Teknik montaj süreci,

- Teknik kontrollerin yapılması,

- Alıcıya iletilmek için kullanılacak kanalların belirlenmesi.

- Çalışmanın kılavuzlarının hazırlanması

- Oluşturulan ürünün alan uzmanları tarafından değerlendirilmesi,

- Farklı çeviri/metin yazımı sorunlarına yönelik çevirmen seçimlerinin tartışılması,

- Tüm engelsiz erişim türlerinde farklı çeviri yöntemlerinin ve uygulamalarının değerlendirilmesi,

- Elde edilen bulguların ve tartışmaların proje tasarımına ve kılavuzlarına yansıtılması.

Aslında bu adımlar temelde çevrilecek ürünün amaç ve hedefler ışığında incelenmesi, çeviri olasılıklarının tartışılması, çeviri taslağının hazırlanması, çevirinin yapılması, çevirinin incelenmesi ve sistematik seçimlerin uygulanması, çevirinin düzenlenmesi (editörlük), çevirinin son taslağının oluşturulması, çevirinin son okumasının yapılması ve çevirinin teslim edilecek sürümünün oluşturulmasını içerir.

Bu süreç bir proje içinde yapıldığında ise en büyük fark tek bir çevirmen veya birkaç çevirmenden oluşan bir çeviri ekibi yerine sürece katkıda bulunan, dönüt sağlayan 
ve her adımda çevirmenle birlikte hareket eden bir danışmanlar, editörler ve alıcı temsilcileri grubunun olmasıdır. Bu katılımcı yapı, bir yandan projelerde çevirmenin işini kolaylaştırır; çünkü soru sorup cevap alabileceği uzmanlar vardır. Ancak, bir yandan da çevirmenin iş yükü artar; çünkü bütün seçimlerini açıklamak ve/ya anlatmak zorunda kalacaktır. Eleştirel bir yaklaşımla ele alınan ürününü kendi düşünceleriyle birlikte eşgüdüm sonunda oluşan görüşler doğrultusunda şekillendirmek zorundadır.

Kısacası, engelsiz erişim için çeviri projelerinde proje yönetiminin uygulama aşamasında çevirmenler, editörler, alıcı grubu temsil eden kitle ve proje koordinatörü birlikte çalışarak planlama aşamasında ortaya konan fikirlerin somut çıktılarını oluştururlar ve bu süreci de kılavuzları oluşturmak için kayıt altına alırlar. Bu süreç, projenin en çok emek sarf edilen zorlu aşamasıdır.

\section{Engelsiz Erişim için Çeviri Projelerinin Kontrol/Doğrulama/Odak Grubu Araştırmaları Aşamasında Dikkat Edilecek Konular}

Her projenin her aşamasında kontrol mekanizması işler; ancak ortaya somut bir çıktı konduğunda bu çıktının 'doğruluğunun' ve 'etkinliğinin' bir odak grubu çalışması ya da bir anket çalışması ile doğrulanması aşaması bundan apayrı bir mekanizma gerektirir.

Krueger ve Casey (2009; 2010, ss. 378-380) projelerde odak gruplarının çeşitli amaçlarla kullanıldıklarını anlatırlar: Birincisi, alıcıların gereksinimlerini belirlemek için odak grubu çalışmalarını kullanmaktır. Engelsiz erişim için çeviri projelerinde bu merkezî bir önemdedir. Engelli alıcıların 'gerçeklerini bilmek ve anlamak' projenin başarılı olabilmesi için olmazsa olmaz bir unsurdur.

İkincisi, bir değişikliği başlatmak için odak grupları ile çalışılabilir. Örneğin, Türkiye'de daha önce Sağır çocuklar için sadeleştirilmiş altyazı çevirisi yapılmadığı için ve sözü edilen projede bu ilk defa yapıldığı için bu değişik uygulamanın tanıtılması ve alıcı grubun tepkilerinin ölçülmesi için odak grubu çalışması çok değerlidir. Alıcı grup belki de sadece işaret dili ile çeviri talep edecek, örneğin ayrıntılı altyazı çevirisini tercih etmeyecektir. Ya da iki sürümün eşerişimle verilmesini isteyecektir (bkz. Okyayuz \& Kaya, 2020).

Üçüncü olarak, odak grubu çalışmaları özellikle de çeviri projelerinde seçeneklerin tartışılması açısından önemli olacaktır. Örneğin, odak grubundan gelen dönüşlerde çocuk alıcıların görsel-işitsel ürünlerdeki bazı eski özel isimleri (Küheylan gibi) anlamadıkları tespit edilirse, bir sonraki projede bu bilgi yapımcılar ile paylaşılabilir ve bu dönütlerden ve bulgudan yola çıkarak belki de bazı daha farklı çeviri stratejileri geliştirilebilir.

Dördüncü olarak odak grubu çalışmalarından veriler toplanır. Beşinci olarak da veriler proje bulgularının ve sonuçlarının anlamlandırılması için önemlidir. Altıncı ve son olarak da projenin etkisini tartmak için odak grubu çalışmaları yönetilir.

Söz konusu projede odak grubu çalışmasına azami önem verilmiştir. Birden fazla bileşeni bulunan projede farklı odak grupları ile çalışmak, ardından onlardan alınan geri dönütleri sayılar, grafikler ile somutlaştırarak, benzer çalışmaları yapacak araştırmacılara 
da yararlı olacak şekilde yorumlamak gerekmiştir. Nicel veriler ilk aşamada ürünün amacına hizmet edip etmediğini somut olarak ölçmek için çok değerli olmuştur. Ancak nitel verilerden (odak grubu çalışması içindeki yarı yapılandırılmış sorulara cevaplardan) elde edilen bilgiler de hem gelecekteki çalışmaların ne olması gerektiği konusunu aydınlatmış, hem de bu proje ile ilgili olarak (proje kapsamında işveren için önemli bir unsur olan) 'memnuniyeti' ölçmekte faydalı olmuştur.

Odak grubu çalışmalarına başlamadan dikkate alınması gereken en önemli konu bu bağlamda izinlerin tamamlanmasıdır. Proje desteğinin bağlı olduğu gruba göre süreç farklılık gösterse de, katılımcılardan onay formu alınması (söz konusu katılımcı çocuksa ebeveyn onay formunun sunulması) temel teşkil eder. Söz konusu projede katılımcının konumuna göre ses kaydı alınarak da onay formlarının teyit edilmesi gerekmiştir. İzinler alınırken odak grubu sorularının hazırlanıp uzmanların denetiminden geçirilmesi ve isteniyorsa etik kurulunun onayına da sunulması, talep edilen düzeltmelerin yapılması önemlidir.

Katılımcı profilleri de projeye veri toplamak için yapılan tüm girişimlerde merkezî önemdedir. Örneğin, söz konusu projede işitme engelli ve ana iletişim dili Türk işaret dili olan çocuklarla çalışıldığında, Sağır bir birey odak grubu çalışmalarında kullanılmıştır. Bireylerin soracağı sorular ise ilk önce taslak olarak ekip tarafından hazırlansa da, bir çocuk gelişimi uzmanı ve başka ilgili uzmanlarca çocuk alıcının erişilebileceği bir dil ve biçemde ve hatta formatta düzenlenmiştir.

Odak gruplarına sorulacak olan soruların dikkatle ve araştırmaya hizmet edecek şekilde hazırlanması kadar, kişisel verilerin korunması kapsamında saklanması da önemlidir. Özellikle örneğini verdiğimiz projede olduğu gibi birden fazla odak grubu ile çalışılacak durumlarda soruların gruplara özel hazırlanması da dikkate alınması gereken bir başka konudur.

Yukarıda da belirttiğimiz gibi söz konusu projede farklı bileşenler olduğu için ilk odak grubu çalışması işitme engelli ve sağır odak grubu çalışması olmuştur. Bu bağlamda işaret dili çevirisi 3-6 yaş odak grubu soruları, işaret dili çevirisi 6-17 yaş odak grubu soruları, ayrıntılı altyazı çevirisi 6-17 yaş odak grubu soruları hazırlanmış ve sorulmuştur. ikinci olarak görme engelli odak grubu çalışması yürütülmüş, bu bağlamda betimlemeli çizgi filmler/programlarla ilgili odak grubu görüşmeleri yapılmıştır. Bu aşamada çocuklara olduğu kadar ebeveynlerle de görüşmeler yapılmıştır.

İşaret dili çevirisi 3-6 yaş odak grubu sorularına verilen yanıtlar, işaret dili çevirisi 6-17 yaş odak grubu sorularına verilen yanıtlar, ayrıntılı altyazı çevirisi 6-17 yaş odak grubu sorularına verilen yanıtlar, grafiklere dökülmüş, yaş dağılımları göz önünde tutularak her bir soruya verilen yanıtlar yorumlanmış, projenin sonucunda alıcı kitleyi tatmin eden, kitlenin programlara erişimini sağlayan ürünler ortaya konup konmadığı tartışılmıştır. Aynı şekilde görme engelli odak grubu çalışmasında da çeşitli sorulara verilen cevaplardan yola çıkılarak belli yüzdelere erişilmiş, çocukların söz konusu programlardaki ifadeleri duyabilme, anlayabilme ve takip edebilme oranları belirlenerek, bu konudaki görüşleri alınmıştır. Çocukların beğenileri ve söz konusu programı izlemeye yönelik istek durumları da hesaba katılmıştır. Anne-babalar da farklı 
gruplardan (çocuğu görme engelli olan annelerin bulguları; görme engelli olup, çocuğu gören annelerin görüşleri) seçilerek onların görüşlerine de yer verilmiştir.

Son olarak, projenin sonuçlanmasıyla birlikte bir proje sonuç raporu kaleme alınır. Burada projenin ana hedefleri ve kapsamı yeniden tekrarlanarak, projenin ana hatları yeniden anlatılır, proje süresi ve proje kapsamında gerçekleştirilen faaliyetler ifade edilir ve elbette, kapsamlı bir kaynakçanın eklenmesi de beklenir.

\section{Sonuç ve Öneriler}

Her ne kadar çalışmamızın odak noktası projelerin döngüsü olsa da, son olarak engelsiz erişim projelerinde (araştırmanın doğası gereği) özellikle dikkat edilmesi gereken birkaç ek noktaya da değinmek yerinde olacaktır. Bu tür projeler, çalışmada örneklerden anlaşılacağı üzere kalabalık ve farklı uzmanlık alanlarından gelen ekiplerin eşgüdümlü gerçekleştirdiği çalışmalardır. Katkıda bulunan kişi sayıları ve uzmanlık dağılımları bazı çeviribilim odaklı projelere kıyasla çok fazla olabilir. Dolayısıyla, özellikle proje sürecinin iyi yönetilmesi önem kazanır.

Ayrıca, son adımdaki engelli alıcı odaklı çalışmalarda da (ister anket ister odak grubu çalışması, ister yarı yapılandırılmış mülakat yapılsın) birçok farklı uygulama (erişimin sağlanması için) gerekecektir.

Uygulanabilir ve uygulamaları ve sonuçları doğrulanabilir projelerde farklı aktörlerin bakış açısı farklılıkları projelere tek bir alanda uzmanlaşmış profesyonellerin getireceğinden kimi zaman çok daha zengin olmaktadır. Bu anlamda, projelere katkıda bulunan tüm araştırmacılar süreçte belli bir 'edinim, zenginleşme' yaşamaktadır.

Çalışmamızın başında da belirttiğimiz gibi çeviribilimin disiplinlerarası doğasının iyice ön plana çıktığı günümüzde farklı alanlardan gelen araştırmacıların bir arada çalışarak, somut verilere ulaşabilmesi için projeler en önemli araçlardır. Tek bir araştırmacının tek başına uzun yıllarda yapabileceği pek çok araştırma konusu projeler sayesinde ele alınabilmekte ve alana katkı sağlanmaktadır. Sosyal bilimler alanında sürekli proje çağrılarının yapıldığı, desteklerin verildiği günümüzde, proje yapmak isteyen araştırmacılara yol göstermesi amacıyla anlatmaya çalıştığımız ve örnekler verdiğimiz bu çalışmamızın alana katkı sağlaması ve özellikle engelsiz erişim ve çeviribilim ekseninde alana katkısı yadsınamaz araştırmalara ek olarak, somut ürünlerin ortaya konabildiği projeleri teşvik etmesi temennimizdir.

\section{Kaynakça}

About

project.

EASYTV.

(2016)

https://easytvproject.eu/\#: :text=EasyTV\%2C\%20a\%20European\%20Horizon\%202020, hearing\%20loss\%20and\%20sight\%20loss).

Bozkurt, S., \& Okyayuz, Ş. (2020). Türkiye'de sağır ve işitme engelli çocuklar için ayrıntılı altyazı çevirisi hakkında bir araştırma: uygulamada sadeleştirme. Çeviribilim ve Uygulamaları Dergisi, (29), 139-160. DOI: 10.37599/ceviri.824787 
Bologna Translation Service. (t.b.). European Commission. https://cordis.europa.eu/project/id/270915

Boğaziçi Üniversitesi BAP İdari Koordinatörlüğü. (2020). Bilimsel araştırma projeleri el kitabı. https://arastirma.boun.edu.tr/tr/bap/bap-idari-koordinatorlugu/bap-el-kitabi-treng

Caietti, N. (2018). Strategies for successful project execution. Project Manager. https://www.projectmanager.com/blog/project-execution

Coe, S., \& Wapling, L. (2010). Practical lessons from four projects on disability-inclusive development programming. Development in Practice, 20(7), 879-886. DOI:10.1080/09614524.2010.508109

Creswell, J., \& Creswell, D. (2018). Research design: qualitative, quantitative and mixed method approaches (5. edition). Sage Publications Inc.

Darnall, R., \& Preston, J. (2016). Project management from simple to complex. University of Minnesota Libraries Publishing.

Dawson, C. (2009). Introduction to research methods. HowToBooks.

EACEA-Education, Audiovisual and Culture Executive Agency. (2020). Literary translation action. European Commission. https://eacea.ec.europa.eu/creativeeurope/actions/culture/creative-europe-culture-literary-translation_en

EASIT- Easy Access for Social Inclusion Training. (2016). https://pagines.uab.cat/easit/en/content/results

EU Calls. (2020). Get Access to EU Funding. https://eucalls.net/.

Hacettepe Üniversitesi Bilimsel Araştırma Projeleri Koordinasyon Birimi. (2021). http://research.hacettepe.edu.tr/

Harpur, P. (2017). Nothing about us without us: the UN convention on the rights of persons with disabilities. A. Leithner \& K. Libby (Ed.), Oxford Research Encyclopedia of Politics içinde (s. 1-20). Oxford University Press. DOI: 10.1093/acrefore/9780190228637.013.245

Hatim, B. (2013). Teaching and researching translation. Routledge

HELIOS- A Context-Aware Distributed Social Networking Framework. (2018). European Commission. https://cordis.europa.eu/project/id/825585

ImAc- Immersive Accessibility. (2020). European Commission. https://cordis.europa.eu/project/id/761974

IMPACT. (2020). European project IMPACT - Home Inclusive Method Based on the Perception of Accessibility and Compliance Testing. https://impact-access.eu/

Krueger, R. A., \& Casey, M.A. (2009). Focus groups: a practical guide for applied research (4. edition). Sage.

Krueger, R. A. \& Casey, M.A. (2010). Focus group interviewing. J. Wholey, H. Hatry \& K. Newcomer (Ed.), Handbook of practical program evaluation (3. edition) içinde (s. 378-403). Wiley.

Kruger, A., Wallmach, K., \& Munday, J. (2011). Corpus based translation studies: Research and application. Continuum.

LEAD-ME-Leading Platform for European Citizens, Industries, Academia and Policymakers in Media Accessibility. (2020). Faculty of Sciences. https://www.pmf.uns.ac.rs/en/2020/06/03/lead-me-en/.

Lewinson, M. (2011). Key components of successful project management. https://mymanagementguide.com/key-components-of-successful-projectmanagement/ 
LTA. (2020). Live Text Access: A European Project. https://Itaproject.eu/?page_id=291

Marais, K. \& Meylaerts, R. (Ed.). (2019). Complexity thinking in translation studies: methodological considerations. Routledge.

MediaVerse. (2020). About. https://mediaverse-h2020.eu/

Mellinger, C. D. \& Hanson, T.A. (2017). Quantitative research methods in translation and Interpreting studies. Routledge.

Munoz Martin, R. (2016). Reembeding translation process research. John Benjamins.

Okyayuz, A. Ş. (2019). Görsel-işitsel çeviri ve engelsiz erişim. Siyasal Kitabevi.

Okyayuz, A. Ş., \& Kaya, M. (2020). Disability and the implication of coaccessibility: a case study on accessibility to the media in Turkey. Media, Culture \& Society, 42(6), 987-1002. DOI:10.1177/0163443720908133

Orero, P., \& Matamala, A. (2018). Standardising accessibility: transferring knowledge to society. Journal of Audiovisual Translation, 1 (1), 139-154.

RAD- Researching Audio Description: Translation, Delivery and New Scenarios. (2019). Media accessibility platform. https://mapaccess.uab.cat/projects/researching-audiodescription-translation-delivery-and-new-scenarios

Rajkumar, S. (2010). Art of communication in project management. PMI ${ }^{\circledR}$ Research Conference: Defining the Future of Project Management, Washington, DC, Newtown Square, PA: Project Management Institute. https://www.pmi.org/learning/library/effectivecommunication-better-project-management-6480

Saldanha, G., \& O’Brian S. (2013). Research methodologies in translation. Routledge.

SEBEDER-Sesli Betimleme Derneği. (2020a). Projelerimiz. http://sebeder.org/Projelerimiz-17.html

SEBEDER-Sesli Betimleme Derneği. (2020b). Sağır, işitme engelli ve görme engelli çocukların televizyon programlarına engelsiz erişimi projesi. http://sebeder.org/Ayrintili_AltYazi__Isaret_Dili_ve_Sesli_Betimleme-1706.html

Shi, Q., \& Chen, J. (2006). The human side of project management: Leadership skills. Newtown Square, PA: Project Management Institute Inc.

SO-CLOSE- Enhancing Social Cohesion through Sharing the Cultural Heritage of Forced Migrations. (2020). SO-CLOSE. https://so-close.eu/

TRACTION- Opera co-creation for a social transformation. (2020). European Commission. https://cordis.europa.eu/project/id/870610

TR Dizin Proje Tarama. https://app.trdizin.gov.tr/search/projectSearch.xhtml

UMAQ- Understanding Media Accessibility Quality. (2019). Universitat Autonoma de Barcelona. https://pagines.uab.cat/umaq/

Watts, A. (2014). Project management. Victoria, B.C.: BCcampus. https://opentextbc.ca/projectmanagement/chapter/chapter-3-the-project-life-cyclephases-project-

management/\#: :text=A\%20standard\%20project\%20typically\%20has,the\%20project\% 20\%E2\%80\%9Clife\%20cycle.\%E2\%80\%9D

What is project management? APM. (t.b.). https://www.apm.org.uk/resources/what-is-projectmanagement/\#: :text=Project\%20management\%20is\%20the\%20application,a\%20finit e\%20timescale\%20and\%20budget.

Williams, J., \& Chesterman, A. (2002). The map: A beginners guide to doing research in translation studies. St Jerome. 